\title{
Quantitative Analysis of Vitamin C in Lime and Lemon in Vitro: Verification of Vitamin $C$ on the Impairment of Obesity
}

\author{
*Dr.MI Manuha ${ }^{1}$, Prof. PA Paranagama ${ }^{2}$ and Dr BM Nageeb ${ }^{1}$ \\ ${ }^{1}$ Senior Lecturer, Institute of Indigenous Medicine, University of Colombo, Rajagiriya,Sri Lanka \\ ${ }^{2}$ Senior Professor, University of Kelaniya, Kelaniya, Sri-Lanka
}

\begin{abstract}
Deficiency of Vitamin $C$ is one of the causes of obesity. Unani Medical formula encourages lemon juice consumption as a solution to excess weight. This study has been focused on the quantitative analysis of Vitamin C content in Sri Lankan lime and lemon, and a review of how vitamin $C$ impairs obesity. Initially, lime and lemon juices were prepared using fresh matured fruit samples. Next, a 3\% meta-phosphoric acid (HPO3) was prepared and $100 \mathrm{mg}$ of ascorbic acid was dissolved in $100 \mathrm{~mL}, 3 \%$ HPO3. The ascorbic acid standard was prepared. Then, $5 \mathrm{~mL}$ of $3 \% \mathrm{HPO} 3$ was added to $5 \mathrm{~mL}$ of Ascorbic acid standard. Ascorbic acid content was determined separately for both fruit juices using the dye 2,6 Di-chlorophenol Indophenol by Visual Titration method. The pink color was observed as the endpoint to calculate the Vitamin C content. The average Vitamin $C$ in $100 \mathrm{~mL}$ lime and lemon juice was $47.16 \mathrm{mg}$ and $32.7 \mathrm{mg}$, respectively. The review part concluded that Vitamin C reduces the serum leptin level, increases the production of $L$ carnitine, improves the lipid profile, CRP, IL-6, FBG and reduces the inflammatory biomarkers in obese individuals. As lime juice has more Vitamin $C$ than lemon juice, lemon juice can be substituted by lime to reduce excess weight.
\end{abstract}

Key words: Ascorbic Acid, Vitamin C, Lime, Lemon, Obese.

\section{INTRODUCTION}

Overweight and Obesity is globally increasing at an alarming rate. It has been found that worldwide obesity has nearly tripled since 1975. Further it explains that in 2016, more than 1.9 billion adults, 18 years and older, were overweight. Of these over 650 million were obese [1]. According to UNICEF report, obesity rate of Sri Lankan women exceeds $45 \%$ as explained by the Sri Lankan newspaper Daily Mirror [2]. Overweight and obesity are major risk factors for a number of chronic diseases, including diabetes, cardiovascular diseases and cancers [3].

Hence, world is seeking a better solution for overweight and obesity and is trying to probe a way to reduce excess weight through allopathic and alternative medical systems. Unani is an age old medical system from ancient Greek and enrichened in Arabia also known as Greco-Arabic medicine. Unani medicine explains many causes to obesity and many solutions for it. It mentions that the daily use of lemon may help to reduce obesity [4]. An animal study done in Japan indicated that the feeding of lemon polyphenols suppressed the body weight and body fat accumulation by increasing peroxisomal $\beta$-oxidation through up-regulation of the mRNA level of acyl-CoA oxidase (ACO) in the liver and white adipose tissue [5].

Lime and lemon are from the same species and are often confused with each other. Unlike lemon, lime is a freely available fruit in any shops and both contain Vitamin C in different quantities. Thus far, no Sri Lankan studies have been conducted on Vitamin C quantities present in lime and lemon. Further, Nutritionist Carol Johnstons' also viewed that, in order to lose weight there must be a subtle change in our diet such as to increase vitamin $\mathrm{C}$ intake [6]. Therefore this study was meant to find out whether the lime consumption can be substituted to lemon, in overweight and obese people based on the quantity of Vitamin C. Quantitative analysis of the vitamin C content in Sri Lankan lime and lemon with the review of how vitamin C impairs obesity was aimed in this study.

\section{MATERIALS AND METHODS}

\subsection{Quantitative analysis of vitamin C}

Quantitative analysis of vitamin C was done by titration method and the process was carried out at Industrial Technology Institute, Bauddaloka Mawatta, Colombo-7. 


\subsubsection{Sample preparation}

Samples of fresh and ripe lime and lemon fruits were purchased from the local market. The pulp and seeds were separated and fresh juices of lime (Citrus aurantifolia) and lemon (Citrus limonum) were extracted, separately.

\subsubsection{Procedure}

Standard methods were used to estimate ascorbic acid [7]. First, 3\% metaphosphoric acid was prepared. $100 \mathrm{mg}$ of ascorbic acid dissolved in $100 \mathrm{~mL}, 3 \%$ metaphosphoric acid. Ascorbic acid standard was prepared by $10 \mathrm{~mL}$ aliquat from the above and again top up to $100 \mathrm{~mL}$ with $3 \%$ metaphosphoric acid. Then, $5 \mathrm{~mL}$ of $3 \%$ metaphosphoric acid was added to $5 \mathrm{~mL}$ of Ascorbic acid standard.Ascorbic acid content was determined separately for both fruit juices using the dye 2,6 Dichlorophenol Indophenol by Visual Titration method. Formation of pink colour was observed as the end point to calculate the ascorbic acid content. Calculation was carried out using the following formula given below. Average dye factor was 0.126.

\subsubsection{Quantification of Vitamin C}

Quantification was carried out using the following equation formula to calculate the Vitamin C concentration on samples in mg / $100 \mathrm{~mL}$.

$$
\underset{\text { Per } 100 \mathrm{~mL}}{\operatorname{mef} \text { Ascorbic acid }=} \frac{\text { Titrate } \times \text { Dye factor } \times \text { volume made up } \times 100}{\begin{array}{c}
\text { Aliquot of extract } \times \\
\text { taken for estimation }
\end{array}} \begin{gathered}
\text { volume of sample } \\
\text { taken for estimation }
\end{gathered}
$$

\subsection{Review the role of Vitamin $\mathrm{C}$ to impair obesity}

\subsubsection{Collecting research data}

A literature search of Vitamin C on impairing obesity was collected from published journal articles. Online electronic databases PubMed, MeSH advanced and Google scholar were searched to filter the articles up to August 2019 using search terms in English publications. The following search terms were used to filter the data.

- $\quad$ Made queries for Vitamin C

$$
\begin{array}{ll}
\circ & \text { Vitamin C } \\
\circ & \text { Ascorbic acid }
\end{array}
$$

- $\quad$ Made queries for impair obesity

$$
\begin{aligned}
& \circ \text { Impair obesity or Reduce weight } \\
& \circ \text { BMI }
\end{aligned}
$$

Combining these two main queries the data was filtered at PubMed.

\subsubsection{Inclusion criteria}

Intervention/s done in human only (double blind, placebo control, RCT trials)

\subsubsection{Exclusion criteria}

Animal studies

Duplicate publications

Unpublished and directly not related to the topic

\section{RESULTS AND DISCUSSION}

\subsection{Quantitative analysis of vitamin $\mathrm{C}$}

This study found that the mass of ascorbic acid in $100 \mathrm{~mL}$ of lime juice was within the range $45.05 \mathrm{mg}$ to $49.27 \mathrm{mg}$. Similarly, the mass of ascorbic acid in $100 \mathrm{~mL}$ of lemon juice was within the range $31.26 \mathrm{mg}$ to $34.14 \mathrm{mg}$. The average ascorbic acid in 100 $\mathrm{ml}$ lime juice and lemon juice were $47.16 \mathrm{mg}$ and $32.7 \mathrm{mg}$, respectively.

Vitamin C (Ascorbic acid) being a water soluble compound is easily absorbed but not stored or synthesized in the body. Further, the average half-life of ascorbic acid in adult human is about 10-20 days [8]. It is therefore, important to take food with high vitamin $\mathrm{C}$ content in our daily diet.

In a quantitative study it was found that lime contains $306 \mathrm{mcg}$ of Vitamin $\mathrm{C} / \mathrm{mL}$ [9]. Violeta et al reported that lemon juice contains more vitamin $C$ than lime juice [10]. In another study it was mentioned that vitamin $C$ in lemon and lime juice are 1.44 and $1.38 \mathrm{~g} / \mathrm{oz}$, respectively [11]. Opposing to the above studies, the present study revealed that in Sri Lanka, lime juice contains more vitamin $\mathrm{C}$ than lemon juice. 
Okenwa et al revealed that the 3 citrus family fruits in Nigerian origin, the amount of Vitamin $\mathrm{C}$ content was higher in unripe fruits of sweet oranges (Citrus sinensis), than the ripe ones. Further, lemon (Citrus lemonum) fruits are second to oranges, containing Vitamin $\mathrm{C}$ within the ranges of 50.1 - $35 \mathrm{mg} / 100 \mathrm{~g}$ juice under different temperature surroundings [12].

\subsection{Role of Vitamin $C$ to reduce excess weight}

3.2.1 Pathophysiology of obesity related with Vitamin C

\subsubsection{Leptin levels and vitamin $\mathrm{C}$}

Leptin (Greek leptos means "thin"), the "satiety hormone" is synthesized and secreted primarily by adipocytes (fat cells). This hormone is important to keep the body thin. It is present in blood serum in direct proportion to the amount of adipose (fat) tissue and as fat cells become enlarged in obesity, they secrete more leptin. This hormone communicates with the central nervous system to regulate energy intake and energy stores in the body so that the hypothalamus can efficiently maintain a stable body weight [13]. The process begins when the brain notes the amount of leptin secreted by fat cells. If the brain determines these leptin levels are normal, it shuts off the signal to store extra calories as fat. The body no longer feels like eating because the brain, with the help of leptin, has given the full signal [14].

However, in most overweight/ obese patients, leptin levels are excessively high due to leptin resistance, a process similar to the concept of insulin resistance. Once a person becomes leptin resistant, the body experiences a difficult time transporting leptin past the blood-brain barrier to the hypothalamus where it is needed to send satiety signals. Now, blood levels of leptin may be excessively high but brain levels are insufficiently low, resulting in food cravings and weight gain. The brain believes that the body is in a starving state and tells it to continue to store fat [15].

\subsubsection{L-carnitine and Vitamin C}

L-carnitine is an amino acid which plays a main role in the production of energy by transporting fatty acids into the cells' mitochondria. Mitochondria burn these fats to create usable energy. Body can produce L-carnitine out of the amino acids lysine and methionine. Plenty of Vitamin C is essential to produce L-carnitine [16].

\subsubsection{Vitamin C and weight reduction in obesity}

A study found that an increased intake of Vitamin $\mathrm{C}$ could reduce the belly fat that accumulates around the abdomen [17]. Further a Mexican study revealed that the prevalence of vitamin $\mathrm{C}$ deficiency in overweight and obese women was significantly higher than normal weight women and Vitamin C was negatively associated with BMI and leptin levels [18].

A Randomized Controlled Trial revealed that vitamin C (500 mg twice a day) for 8 weeks has a potential in anti-inflammatory effect by improving the biomarkers such as hs-CRP, IL-6, and FBG in hypertensive and/or diabetic obese patients [19]. Plasma C-reactive protein (CRP) is an inflammatory biomarker that predicts cardiovascular disease. Vitamin $\mathrm{C}$ could reduce inflammatory biomarkers associated with obesity [20].

Further, adiposity-related inflammation in overweight and obese increases the serum hepcidin level and decreases dietary iron absorption. Higher intake of ascorbic acid enhances the iron absorption in obese individuals to improve iron status [21].

Vitamin C (Ascorbic acid) has antioxidant properties [22], [23]. Antioxidants are nutrients that block some of the damage caused by free radicals and by which it would reduce the occurrence of chronic diseases such as obesity, diabetes and even cancers. Studies revealed that In addition to the antioxidant activity, researches disclosed that Vitamin $\mathrm{C}$ reduces significantly the serum LDL cholesterol and triglycerides and a non-significant elevation of serum HDL cholesterol [24].

A vitamin C deficiency reduces the body's synthesis of L-carnitine, an amino acid that the mitochondria need to burn fatty acids. Nutritionist Carol Johnstons' view is that, in order to lose weight there must be a subtle change in our diet such as simply to increase vitamin $\mathrm{C}$ intake [6].

\section{CONCLUSION}

As lime juice has more vitamin $\mathrm{C}$ than lemon juice, lime juice can be substituted for a long term intervention (which focuses on weight reduction) instead of lemon juice. Unlike lemon, lime is abundantly available all over the island and hence lime is also more convenient as a commodity. Thus lime is a better and economically feasible remedy to battle obesity compared to lemon.

The review concluded that Vitamin $\mathrm{C}$ reduces the serum leptin level, increases the production of $\mathrm{L}$ carnitine, improves the biomarkers such as LDL cholesterol, triglycerides, CRP, IL-6, FBG and reduces the inflammatory biomarkers in obese. Vitamin C 
is a high potential anti-oxidant and provides defense against the oxidative stress produced by low-grade inflammation and the accompanying free radicals that can damage the body's cells.

\section{ACKNOWLEDGEMENT}

The authors thank Mr. MN Ishaaq Ahamed and Mr MNM Ayoob for their contribution for this review.

\section{CONFLICT OF INTEREST}

The authors declare that there is no conflict of interest.

\section{REFERENCES}

1. WHO. Obesity and overweight. (2018).Retrieved from the website https://www.who.int/news-room/factsheets/detail/obesity-and-overweight on 22.08.2019.

2. Daily Mirror Online. SL women obesity rate exceeds $45 \%$ : UNICEF. (02.10.2019). Retrieved from the website http://www.dailymirror.lk/149680/SL-women-obesity-rate-exceeds-UNICEF on 22.08.2019

3. Kumar, P \& Clark, M. Clinical Medicine, A Text book for Medical students and Doctors. Seventh Edition. WB Sounders, Edinburgh, London. 2009.

4. Ummul, F. \& Abdur-Razzack, M. A Hand Book of Common Remedies in Unani System of Medicine. CCRUM (Ministry of Health and Family Welfare), Government of India, New Delhi. 1986.

5. Yoshiko, F., Masanori, H., Miki, O., et al. Lemon Polyphenols Suppress Diet-induced Obesity by Up-Regulation of mRNA Levels of the Enzymes Involved in $\beta$-Oxidation in Mouse White Adipose Tissue. J Clin Biochem Nutr. $2008: 43$ (3), 201-209.

6. Johnston,C.S. Strategies for healthy weight loss: from vitamin C to the glycemic response. Journal of American College of Nutrition. 2005. 24 (3): 158-65.

7. AOAC. Official Method of Analysis of AOAC International. Method 967.21 e Ascorbic Acid in Vitamin Preparations and Juices: 2,6-Dichloroindophenol Titrimetric Method. Maryland, USA. 2006

8. Hellman, L., \& Burns, J.J. (). Metabolism of L-ascorbic acid-1-C ${ }^{14}$ in man. Journal in Biol Chem. 1958: 230 , 923930. [PubMed Abstract]

9. Izuagie, A.A., \& Izuagie, F.O. Iodimetric Determination of Ascorbic Acid (Vitamin C) in Citrus Fruits. Research Journal of Agriculture and Biological Sciences. 2007, 3(5), 367-369.

10. Violeta, N., Ion, T., \& Mira, E.I. HPLC Organic Acid Analysis in Different Citrus Juices under Reversed Phase Conditions. Not. Bot. Hort. Agrobot. Cluj. 2010 : 38 (1), 44-48

11. Kristina, L.P., Stephen, Y.N., Ross, P.H., and Dean, G.A. Quantitative Assessment of Citric Acid in Lemon Juice, Lime Juice, and Commercially-Available Fruit Juice Products. J Endourol.2008. 22(3), 567-570.

12. Okenwa U L. Quantitative Estimation of Ascorbic Acid Levels in Citrus Fruits at Variable Temperatures and Physicochemical Properties. International Journal of Chemical and Biochemical Sciences. IJCBS, 5(2014):67-71. (ISSN 2226-9614)

13. Fantuzzi, G., Sennello, J.A., Batra, A., Fedke, I., Lehr, H.A., Zeitz, M., \& Siegmund, B. Defining the role of T cellderived leptin in the mo ulation of hepatic or intestinal inflammation in mice. Clin Exp Immunol. 2005, 142 (1):31-8.

14. Vinay-Kumar., Abul,K., \& John C.A. Robbins Basic Pathology, 9th edition, Elsevier. 2012

15. Radic, R., Nikolic,V., Karner, I., Kosovic, P., Kurbel, S., Selthofer, R., Curkovic, M. Circadian rhythm of blood leptin level in obese and non-obese people. Coll Antropol. 2003, 27 (2):555-61.

16. Rudy M. L-Carnitine: Benefits, Side Effects, Sources and Dosage. healthline. 2018, Nov.6 Article retrieved from the website https://www.healthline.com/nutrition/l-carnitine on 02.02.2019.

17. Stephen, D. NUTRA: Free News Letter. 2007. Vitamin C and dairy linked to less abdominal weight. Retrieved from the website http://www.nutraingredients.com/ on 15.04.2019

18. Olga PG, Dolores R, Shadia E, Karina de la T, María del C C\& Jorge LR. Vitamin C deficiency is associated with obesity in rural Mexican women. THE FASEB journal. April 2009. [PubMed] [Abstract]

19. Ellulu MS, Rahmat A, Patimah I, Khaza'ai H, Abed Y. Effect of vitamin C on inflammation and metabolic markers in hypertensive and/or diabetic obese adults: a randomized controlled trial. Drug Des Devel Ther. 2015 Jul 1;9:3405-12. doi: 10.2147/DDDT.S83144. eCollection 2015. [PubMed] [Abstract]

20. Block G, Jensen CD, Dalvi TB, Norkus $\quad$ EP, Hudes $\quad$ M, Crawford $\quad$ PB, Holland N etal. Vitamin C treatment reduces elevated C-reactive protein. Free Radic Biol Med.2009 Jan 1;46 (1):70-7. doi: 10.1016/j.freeradbiomed.2008.09.030. 
21. Cepeda-Lopez AC, Melse-Boonstra A, Zimmermann MB, Herter-Aeberli I. In overweight and obese women, dietary iron absorption is reduced and the enhancement of iron absorption by ascorbic acid is one-half that in normal-weight women. Am J Clin Nutr. 2015 Dec; 102 (6):1389-97. doi: 10.3945/ajcn.114.099218. Epub 2015 Nov 11. [PubMed] [Abstract]

22. Proteggente, A.R., Pannala, A.S., Paganga, G., Van Buren, L.,Wagner, E.,Wiseman, S., Van-De-Put, F., Dacombe, C. , \& Rice-Evans, C.A. The antioxidant activity of regularly consumed fruit and vegetables reflects their phenolic and vitamin C composition. Free Radical Research. 2002, 36 (2) , 217-33.

23. Vojdani, A., Bazargan, M., Vojdani, E., \& Wright, J. (2000). New evidence for antioxidant properties of vitamin C.Cancer Detection and Prevention, 24 (6),508-23.

24. McRae, M.P. (2008). Vitamin C supplementation lowers serum low-density lipoprotein cholesterol and triglycerides: a meta-analysis of 13 randomized controlled trials. Journal of Chiropractic Medicine, 7 (2): 48-58. doi: 10.1016/j.jcme 